\title{
Kracauer, S. (2015). Os empregados. Lisboa: Antígona.
}

\author{
Rita Ribeiro
}

Quando Siegfried Kracauer, intelectual alemão que viveu entre 1889 e 1966, escreveu Os Empregados, o mundo estava às portas de uma fatídica década de recessão que haveria de precipitar a emergência dos fascismos na Europa e a guerra mundial de 19391945. Kracauer, judeu e marxista, não podia imaginar que poucos anos depois estaria em fuga da Alemanha nazi e procuraria refúgio nos Estados Unidos da América, onde permaneceu até ao fim da vida. Publicada em 1930, a obra foi destruída pelo regime de Hitler e só décadas depois foi sendo resgatada.

Como para outros intelectuais europeus da sua época, o pensamento de Kracauer não pode ser situado num território singular do conhecimento ou num campo estreito de interesses. Arquiteto e engenheiro de formação, foi no domínio das artes, filosofia e ciências sociais que situou a sua produção intelectual. Kracauer deixou importantes contributos para a sociologia da arte e da cultura, nomeadamente sobre cinema e fotografia, mantendo na sua leitura das manifestações artísticas e culturais uma vincada perspetiva política de matriz crítica marxista.

Em Os Empregados, Kracauer apresenta uma visão quase etnográfica das relações laborais que se estabelecem na Europa saída da Primeira Guerra Mundial e que põem em palco, numa configuração complexa, burguesias e assalariados. $O$ fortalecimento do Estado-Providência, a explosão do consumo e a expansão dos serviços em geral fazem engrossar de forma inédita o grupo dos empregados e aproxima cada vez mais a sua condição laboral da dos proletários que a industrialização criara. Kracauer diz mesmo que se "constitui um exército de reserva industrial de empregados" (p. 17) e distancia-se dos que vêem neste grupo uma nova classe média.

Berlim, onde se situa o trabalho de campo que dá origem à obra, era um formigueiro humano, uma cidade vibrante onde o relançamento da atividade industrial e comercial pós-Primeira Grande Guerra criou uma fração de classe social particular. Empregados na banca, nos escritórios e, sobretudo, no comércio, são homens e mulheres que Kracauer descreve explorados no torno do capitalismo, mas tomados pela ideologia burguesa. Faz-se evidente a contradição entre as relações objetivas de dominação e subalternidade que os empregados enfrentam no trabalho e respetivo salário e a elaboração subjetiva do seu lugar de classe, que se corporiza na fantasia da ascensão social e na participação em estilos de vida com que ambicionam afastar-se dos operários e tornar-se indistintos das classes que emulam. Tornam-se muito vivos os esforços para acentuar a diferença que,

opõe operários a empregados, sentida como uma diferença de classe, embora no essencial e há largo tempo tenha deixado de o ser. (...) Se é verdade 
que um escriturário se diferencia mais de um procurador do que de um ope-

rário especializado, é do primeiro que se considerará colega (pp. 111-112).

Ainda que a análise que Kracauer faz do mundo dos empregados berlinenses seja escorada na visão marxista, esta obra é admiravelmente permeada por um olhar arguto e irónico que mostra uma realidade que se desdobra em múltiplas camadas nem sempre coerentes. Em lugar da vulgata marxista, o que encontramos é a atenção dada à superestrutura e aos processos que no quotidiano elaboram uma cultura dos empregados armadilhada de dispositivos ideológicos de sujeição. É nos interstícios das relações de produção que Kracauer explora os meandros da cultura do capitalismo, recorrendo ao discurso dos seus agentes, empregadores e empregados de diversas categorias, recoIhido em documentos ou entrevistas, mas desmontando sistematicamente o que neles representa a "falsa consciência" de que fala Walter Benjamin numa recensão que fez à obra e é publicada como posfácio desta edição.

O "trabalho intelectual, fácil e limpo" (p. 24), legitimado por diplomas escolares sobrevalorizados, não escapa à racionalização que se impusera já sobre o trabalho industrial na empresa moderna. Seja a dactilografar, a atender clientes ou a somar parcelas na contabilidade, o trabalhador dos serviços é também ele sujeito a um trabalho crescentemente mecanizado, fragmentado e controlado.

A mão-de-obra está dispensada de possuir conhecimentos (...). Exige-se-Ihe apenas uma coisa: atenção. Não tem liberdade; está submetida ao controlo do aparelho que controla, e tem o dever (...) de exigir dos seus nervos uma resistência tanto maior quanto menos atraente for o objecto com que lida (p. 39).

A proletarização dos empregados resulta, por isso, menos ao seu nível salarial do que da perda de autonomia no trabalho; analogamente ao que aconteceu ao artesão quando entrou na fábrica, o empregado é agora uma peça nas rodas dentadas cada vez mais oleadas e impessoais dos serviços.

O controlo sobre os empregados não se confina, todavia, ao exercício das funções profissionais. Kracauer expõe o controlo eminentemente político sobre os trabalhadores em que as empresas investem e dá particular atenção à forma como o desporto e o entretenimento se tornam, diríamos hoje, um instrumento de gestão de recursos humanos ou, numa versão menos ingénua, num instrumento de biopoder, como Michel Foucault o conceptualizou (2004). A condição física, mostrou-a também Kracauer, é cada vez mais para os empregadores um requisito de seleção e um elemento implícito da avaliação dos trabalhadores, de que depende a promoção ou a continuação do contrato laboral. Mas, para além disso, constitui o desporto praticado no contexto do trabalho, tendo como parceiros colegas e chefes, uma forma de capturar as energias do empregado para aquilo a que Kracauer chama "vontade de comunidade (p. 102). Ou seja, ao desporto e ao lazer cabe criar os laços de fidelidade à empresa que o trabalho capitalista rompeu ao reduzi-lo a custo e mercadoria: 
Digamos que as agremiações desportivas se assemelham a postos avançados, destinados a submeter à empresa um campo da alma dos empregados ainda não ocupado. De facto, muitas vezes elas levam a cabo um meticuloso trabalho de colonização (p. 103).

Ao mesmo tempo, a frequência de atividades de lazer enquadradas na empresa é a mais forte concorrência à participação dos trabalhadores nas lutas sindicais, tanto mais importante quanto são os sindicatos o único contra-poder efetivo no mercado capitalista do trabalho. Percebendo a atracão que as atividades lúdicas exercem sobre os empregados, os sindicatos hesitam entre desmascarar a falsa benemerência das empresas e oferecer aos seus associados uma dose similar de recreação, escapismo e busca de pertença. Desporto e entretenimento são, como diz S. Kracauer, "um importante fator de despolitização" (p. 130).

Reflexo da mesma política escultórica da força de trabalho, é a forma como a idade funciona não como repositório de experiência, mas como limiar de indesejabilidade que penaliza quem trabalha porque envelhece a cada dia. Para as empresas, o empregado jovem traz vantagens da maior relevância no mundo dos serviços: boa aparência, resistência física e mental ao labor, salários mais baixos e a docilidade própria dos que ainda não perceberam que a sua diligência é a sua exploração. A idade representa, pois, um recurso de poder ao constituir ameaça sobre os mais velhos que se debatem para a dissimular: "receosos de se verem rejeitados como produtos fora de prazo, mulheres e homens pintam o cabelo, e os quarentões praticam desporto para manter a linha " ( $p$. 33). Não se julgue, porém, que a intimação pesa apenas sobre os que já não têm como esconder as rugas. Kracauer descreve uma situação que nos é hoje familiar: "o certo é que hoje o limite de idade da vida ativa baixou de maneira considerável e, lamentavelmente, aos quarenta anos, muita gente que ainda se sente em plena forma já está, do ponto de vista económico, morta" (p. 6o).

Em Os Empregados é mais do que a cultura de uma sub-classe, a racionalização dos serviços ou a vida urbana de Berlim que Kracauer disseca. É uma ordem social em transformação que o autor surpreende em cada detalhe da vida social que observa. É uma sociedade que, sabemos, prepara caminho para a capitulação perante uma ideologia totalitária.

Os empregados que hoje povoam Berlim e as outras grandes cidades alemã constituem massas cujo modo de vida apresenta um cunho cada vez mais uniforme. (...) uma existência que, além do mais, está sujeita (...) à influência uniformizadora de poderosas forças ideológicas (p. 85).

Os indícios que Kracauer aqui percebe quase intuitivamente, Hannah Arendt (2006) haverá de qualificar como condição para a formação da Alemanha nazi. A massificação não foi uma arregimentação de exércitos, foi a colonização das almas comuns, dos que conheciam a despersonalização de ser uma peça obediente na engrenagem. 


\section{REFERÊNCIAS BIBLIOGRÁFICAS}

Arendt, H. (2006 [1951]). As Origens do Totalitarismo. Lisboa : Dom Quixote.

Foucault, M. (2004). Naissance de la Biopolitique. Cours au Collège de France (1978-1979). Paris: Seuil.

Kracauer, S. (2015). Os empregados. Lisboa: Antígona.

\section{NotA BIOGRÁFICA}

Rita Ribeiro é Professora Auxiliar do Departamento de Sociologia e investigadora do Centro de Estudos de Comunicação e Sociedade (CECS), do Instituto de Ciências Sociais da Universidade do Minho (Braga /Portugal).

E-mail:rmgr@ics.uminho.pt

Instituto de Ciências Sociais, 4710-057-Braga, Portugal.

* Submetido: 08-10-2015

* Aceite: 16-10-2016 